\title{
Who Wants Democracy in China? An Empirical Analysis of Chinese Democratization in Perspective
}

\author{
Gang Wang ${ }^{1}$ \\ ${ }^{1}$ Department of Political Science, University of Zurich, Switzerland \\ Correspondence: Gang Wang, Department of Political Science, University of Zurich, Switzerland. E-mail: \\ wang.ucb@gmail.com
}

Received: December 23, 2015

Accepted: December 25, 2015

Online Published: February 4, 2016

doi:10.20849/ajsss.v1i1.8

URL: http://dx.doi.org/10.20849/ajsss.v1i1.8

\begin{abstract}
The modernization theory suggests that the entrepreneurs and the middle class have a strong demand for democracy with a country's economic development. Yet this conventional wisdom has been challenged in the Chinese context. In the debate on China's democratization, the social groups demanding for democracy in the economic reform have not been well identified. By employing the 2006 China General Social Survey, this empirical research has two interesting findings. First, the members of the Chinese Communist Party (CCP) especially the CCP members of the working class as well as the social elites show a stronger demand for democracy. Second, these groups in favor of democratic principles oppose various democratization activities. These findings imply that the demand for democracy in China is more likely to be an expression of discontent with the current political system rather than the democratic impulses, and the Chinese democratization is not optimistic in the near future.
\end{abstract}

Keywords: democracy, cadre, entrepreneur, middle class, working class

\section{Introduction}

The modernization theory of political development suggests that the entrepreneurs and the well-educated middle class have a strong demand for democracy along with a country's economic development. Inspired by Moore's (1966) famous declaration, "No bourgeoisie, no democracy", China's political transition to democracy has been expected for a long time and some scholars even contend Chinese democratization will be seen in the near future as China has been experiencing rapid economic growth since the end of 1970s (Liu \& Chen, 2012; Rowen, 2007). Yet this conventional wisdom of "the democratic impulses of the middle class" (Tsai, 2005) has been challenged both theoretically and empirically in the Chinese context. If the middle class does not support democratic principles in China, then who wants democracy in China? Do those in favor of democracy support political liberation in practice as well?

By employing the 2006 China General Social Survey (CGSS), this empirical research has two interesting findings. First, the members of the Chinese Communist Party (CCP) especially the CCP members of the working class as well as the cadres and the administrators in State-Owned Enterprises (SOEs) show a stronger demand for democracy. The working class members' preference to democracy is explained as an expression of discontent towards the marginalized political status in the reform while the cadres and administrators' support to democracy may be a response to the pervasive bureaucratic corruption from the insiders' view. Second, these groups who are in favor of democratic principles oppose various democratization activities in practice. The multivariate analysis also identifies that these groups are more satisfied with their economic well-being than other groups. These empirical evidences imply that the demand for democracy in China is more likely associated with people's disappointment with the current political system rather than the democratic impulses, and the Chinese democratization perspective is not optimistic in the near future.

This paper contributes several important implications for studying democratization in comparative studies and Chinese politics. In the framework of modernization theory, entrepreneurs and well-educated middle class are supposed to demand for political freedom as a country's economy grows. Though various theoretical and empirical studies have pointed out this may not be true in transition China, the empirical findings in the paper is not consistent with the conventional wisdom's expectation. First, in some developing countries, the strong preference to democracy may stem from the most discontented groups with government's economic or political 
policies rather than the well-educated middle class. Second, those who demand for democracy in developing countries do not necessarily support democratization as their political demand may just be a signal of disagreement with government policies instead of the legitimacy of the government. Thus in the Chinese context, democratization may not be as optimistic as many advocators predicted.

The rest of this paper proceeds as follows. First, I discuss China's social economic diversity since the end of 1970s and briefly review the democratization theory in the Chinese context. Then I move to the empirical analysis, examining the variables, measurements and findings before the discussion and conclusion.

\section{The Development of Social Economic Diversity in the Economic Reform}

Chinese society in the Mao era is a homogeneous one despite the significant urban-rural gap. Since the end of 1970 s, the China's reform accompanied by a relaxation of controls over economy and society (Perry \& Selden, 2003) has made profound changes in the Chinese society. In rural China, the implementation of the Household Responsibility System and the released Household Registration System not only promoted peasants' income but also gave them much more freedom to make economic decisions and mobilize between rural and urban areas (Liou, 2000). The SOEs reform and the development of private firms certainly promoted the economic opportunities and working mobility in urban China as well. According to the Office of the State Bureau of Business Management, more than 20 million workers were hired in the total number of 1.76 million private enterprises until 2000 (individual household businesses were not included). Certainly, there are many side effects associated with the economic reform. The number of laid-off workers, for instance, has increased rapidly in both absolute measure and a share of the workforce (Naughton, 2003). The number of protests or collective incidents increased from 8,709 in 1993 to 87,000 in 2005 (Yu, 2007) and an estimated 180,000 in 2010 (Demick, 2012). Ironically, many Chinese citizens trust in the Center more than in the local governments (Li, 2004; Lieberthal, 2004). Thus lots of social protests are the "rightful resistance" (O'Brien, 1996; O'Brien \& Li, 2006), economic-oriented rather than political-oriented (Lorentzen, 2013), or the managed political participation (Cai, 2004).

China has been developing a young middle class (Goldman \& MacFarquhar, 1999). Though the specific size of the middle class varies greatly, there is little in doubt that the number of the Chinese middle class grows rapidly (Lieberthal, 2004). Attitudes of the middle class in the survey are pretty ambiguous and there is no concrete evidence to show China's middle class wants to challenge the political status quo (Fewsmith, 2007). Compared to the middle class, the Chinese entrepreneurs are more active in political participation especially among the government-oriented market (Li \& Zhang, 2006). From 1997 to 2002, more than 9000 and 32,000 private entrepreneurs took a seat at People's Congress or People's Political Consultative Conference at or above the county level (Nande, 1997). The political attitudes of the middle class and the entrepreneurs in China imply the rapid economic development may have a negative effect on political liberation. According to Pei (2006), "such growth increases the value of political power, reduces the pressure for political opening, and provides rulers with more resources to co-opt new social groups and repress the opposition."

China's economic decentralization has re-shaped local leaders' behavior as well. On one hand, empirical evidence shows local leaders' political turnover is sensitive to their performance in terms of promoting local economic growth (Chen \& Zhou, 2005; Li \& Zhou, 2005). These findings indicate China's reform strategy has enhanced cadre efficiency and government accountability (Heberer \& Schubert, 2006; Holbig \& Gilley, 2010; Mesquita \& Downs, 2005). On the other hand, the decentralized reform encourages local leaders to pursue their own economic interests rather than closely following Beijing and bureaucratic corruption has been a crucial issue of the CCP (Lieberthal, 2004). According to the 2006 CGSS, the cadre is ranked the top vested interest group during the reform. However, though the number of party members increased from 38 million in 1980 to 70.8 million in 2005, only about five hundred thousand members are categorized into the party elites who hold offices in the formal party apparatus (Brodsgaard, 2002; Lieberthal, 2004).

\section{Demand for Democracy: The Conventional Wisdom in the Chinese Context}

Democracy in comparative politics is widely viewed as a covariate of economic development. Just as Lipset (1959) says, "Perhaps the most widespread generalization linking political systems to other aspects of society has been that democracy is related to the state of economic development." In this framework of modernization theory, the demand for democracy is generally assumed to be rooted in the entrepreneurs and the well-educated middle class. Though optimists advocate various good conditions for China to advance to democracy, few empirical studies discover the evidence that the Chinese middle class demand for political power. On the other hand, pessimists criticize the modernization theory in the Chinese context by focusing on the dependent role of the middle class in the CCP regime. However, democratization may be affected by different factors. No 
demanding for political freedom in a certain group does not necessarily mean democracy is not wanted by other people.

Optimists emphasize how the rapid economic development has transformed China into a state favoring democratization and the Chinese people are unlikely to be satisfied with "richer but no freer" (Li, 2007; Mesquita \& Downs, 2005). Rowen (2007) contends three factors will drive China to a "Partly Free" country in 2015 and a "Free" one around 2025 - continuous rapid economic growth, gradual political changes and released social control. Liu and Chen (2012) hold a similar view and believe "China will embark on democratization around 2020". Besides the economic development, cultural change and the global environment are identified as well in their analysis as favorable factors. Zheng $(1994,2004)$ holds a cautiously optimistic position, and argues the political development in China will take place very slowly as a joint outcome of political competition and social structure and this process cannot be assessed by economic variables alone.

Pessimists explain why the democracy has been delayed in China mainly in two approaches: the improved legitimacy of the CCP regime, the dependent status of the entrepreneurs and the middle class. Pearson (1997) demonstrates China's business owners are not independent and active politically. In Capitalism without Democracy, Tsai $(2005,2007)$ contends China's economic change has not produced an entrepreneur class or middle class as they are either afraid of political persecution or satisfied with the current situation. Various empirical findings correspond to this kind of argument. Chen and Zhong (2000) find that those who support democracy in China prefer social order to political liberty. This implies the Chinese middle class may oppose democratization in reality. Similar results are identified in other studies which reveal a negative correlation between demand for democracy and people's dependent status with the CCP regime (Chen, 2002; Chen \& Lu, 2011). Also, the middle class's attitudes towards democracy may be negatively correlated with China's economic growth. Though Tang (2011) investigates the evidence that the Chinese middle class wants democracy in principle, they are not active in supporting political freedom in practice. Indirect evidence on this point of view can be seen in Li and Zhang's paper (2006). They find entrepreneurs are more likely to be inclined to participate in local politics within the CCP regime among undeveloped markets. All these findings imply China's democratization may be initiated by other actors rather than entrepreneurs.

Another point of view on the communist resilience in China is the improved legitimacy of the CCP regime. According to this approach, the success of economic reform positively affects official efficiency and government accountability (Heberer \& Schubert, 2006), increases the ability of governments to thwart demand for political reform (Mesquita \& Downs, 2005), and appeals the public to strengthen the one-party rule. Under these circumstances, CCP is able to monopolize political power (Yang, 2004) and China's democratization should be waiting until another crisis occurs (Thompson, 2001).

In sum, previous research primarily focuses on the role of the Chinese middle class - no matter whether they are defending or opposing the conventional modernization theory. In the following empirical analysis, I first identify who want democracy in China - if they are not the entrepreneurs and the middle class.

\section{Empirical Analyses}

\subsection{Hypotheses}

I develop and subsequently test four hypotheses in this study. First, compared with the middle class and working class, social elites are more likely to demand for democracy since they benefit most from the economic reforms ('winners'). Second, the CCP members of workers and peasants also have higher demand for democracy since they benefit least from the economic reforms ("losers") and have been politically marginalized in the past decades. Third, although the conventional wisdom implies the demand for democracy is supposed to be consistent with political action in supporting democratization, I suspect that this process may not fit in the Chinese society. Thus, I hypothesize that all the groups who want democracy including social elites and CCP members, are reluctant to support such activities as protesting, striking and mass gathering compared to the rest of the population. Fourth, I hypothesize that groups who demand for democracy perceived better socioeconomic well-beings. This is the contributing factor explaining the co-existence of high demand for democracy and low levels of political activities in the Chinese context.

\subsection{Data and Methods}

The data in this paper comes from the 2006 China General Social Survey, which is jointly conducted by Renmin University of China and Hong Kong University of Science and Technology. The CGSS is a large-scaled social survey project in mainland China employing a multi-stage stratified random sampling method, and covering a wide range of topics such as income, education, employment, marriage and family, health care, insurance, 
attitudes and opinions. From 2003 to 2010 there are 5 waves of CGSS. I apply the 2006 wave simply because this is the only wave covering the survey questions on demand for democracy. The 2006 CGSS includes a national representative sample of adult population aged 18 or above, and consists of 4,951 rural residents and 5,200 urban residents coming from 28 provinces, autonomous regions and municipalities.

\subsection{Dependent Variables}

Demand for Democracy. The dependent variable "demand for democracy" is a binary variable (1=demand for democracy, $0=$ no demand for democracy), and used in the first multivariate regression. It is constructed on the basis of this survey item "As long as high economic growth is maintained, it is not necessary to improve democracy." The designated response options include 5 categories- "strongly disagree, disagree, agree, strongly agree, and no response". Two categories of "strongly disagree" and "disagree" are combined as "1=demand for democracy"; the other two categories of "agree" and "strongly agree" are labeled as " $0=$ no demand for democracy"; and the remaining category of "no response" is not included in the final analysis due to missing values.

Political Rights. Three binary variables of political rights are included in the second multivariate regression as dependent variables $(1=$ supporting political right, $0=$ not supporting). Survey respondents were asked about their opinions regarding the following three political rights: mass gathering, protesting and striking. The 5 response options include "strongly agree, relatively agree, strongly disagree, relatively disagree, and hard to choose." The two categories of "strongly agree" and "relatively agree" are categorized into " $1=$ supporting political right"; the other two categories of "strongly disagree" and "relatively disagree" are indicated by " $0=$ not supporting political right"; and the remaining category of "hard to choose" is dropped from the final analysis.

Perceived Economic Well-beings. Two indicators of perceived economic well-being will become dependent variables in the third multivariate regression. One indicator is based on the survey question, "What is your current income status compared with three years ago?" The original response option is a 4-level hierarchy: $1=$ decreased, $2=$ more or less the same, $3=$ increased, $4=$ hard to say. Again, the category of "hard to say" is dropped from the final analysis. After recoding, the new variable "current income status" will be 3-level categorical variable $(1=$ decreased, $2=$ the same, 3 =increased). The other indicator is based on the survey question, "What is the overall rating of your current happiness?" The response option is a 5 -level hierarchy: 1=very unhappy, $2=$ =unhappy, $3=$ moderately happy, $4=$ happy, $5=$ =very happy.

\subsection{Independent Variables}

CCP Membership. This variable is coded as a binary variable (1=Holding the membership in the China Communist Party (CCP), and $0=$ no).

Group Indicators. Respondent's current social status is another set of variables of central interest in this paper. The survey questionnaire asks respondents, "Which group benefits most in the past 10 years?" There are 11 subgroups listed as response options, including cadres working in governmental institutions (cadres), administrators in state-owned enterprises (SOEs), private entrepreneurs (entrepreneurs), intellectuals and professionals (intellectuals), white-collar, administrators in collective-owned enterprises (COEs), self-employed (getihu), workers, peasants, foreign investors and other. All these segments form a hierarchy of social status. I keep 9 well-defined domestic subgroups and drop two categories - other and foreign investors. Despite the fact that virtually every household has benefited from rapid economic growth, different groups have benefited to very different extents. The respondents reported the ranking of the 9 sectors as follows: the most privileged, also called social elites (entrepreneurs, cadres, SOEs), the middle class (intellectuals, white-collar, self-employed, COEs), and the working class (workers and peasants). Since both governmental cadres and administrators in SOEs are working in state-level entities, the two categories are combined as "public servants" altogether.

\subsection{Control Variables}

Other independent variables include age, gender ( $1=$ male, $0=$ female), minority status $(1=$ non-han minority, $0=$ han ethnicity), education ( $1=$ no formal schooling, $2=$ primary school, $3=$ middle school, 4=high school, and $5=$ some college and above), the logarithm of household income. In order to make the logarithm transformation of the originally continuous variable, only data points with household incomes greater than zero and lower than 1 million renminbi are included in the final analysis. As a result, 32 data points are dropped.

Descriptive statistics are presented for all variables included in the study. T-test is used to examine the differences in demand for democracy between the CCP members versus non-members among various social groups. In order to address the hypotheses described above, I employ a series of multivariate models. First, the effects of social identity on demand for democracy are estimated using logistic regression. Second, whether CCP 
membership plays a role in explaining disparities in demand for democracy is examined by the interaction term of CCP membership and group identity. Third, the effects of group identity on three democratic actions - mass gathering, protest and strike are evaluated by logistic model. Fourth, how different social groups vary in their perceived socioeconomic wellbeing is examined by ordinary least square regression. For all the multivariate models, I include controlling variables such as age, gender, minority status, educational attainment, and household income. For logistic regression, odds ratio, standard errors and significance level are reported. For multiple linear regression, regression coefficients, standard errors and significance level are reported. All statistical analyses are performed using the statistical software package STATA 13.0.

\section{Results}

Table 1 describes the summary statistics for variables included in the analysis for the whole sample. As shown in the table, the elite group only accounts for 5.7 percent of the sample, including 1.5 percent of cadres, 2.1 percent of private entrepreneurs, and another 2.1 percent of administrators in SOEs. The middle class accounts for 15.6 percent of the sample, including 3.2 percent of intellectuals, 11.2 percent of the self-employed, and 1.2 percent of white collars. Females are slightly more than males, $54 \%$ versus $46 \%$, respectively. The mean age is 42 years old, with the youngest 18 years old and the oldest 70. 93.4 percent of the sample belongs to Han ethnicity, and the remaining 6.6 percent are minority ethnic groups, including Zhuang, Hui, Wei, etc. The educational attainment is still distributed unevenly, with 9.9 percent having no formal schooling, 22.3 percent having primary education, 33.2 percent having middle school education, 22.6 having high school or equivalent diploma, and only 12 percent having some college education or above. Since I dropped 32 data points either having zero household income or more than 1 million renminbi, the average household income is around 21,570 renminbi with the lowest 150 and the highest 600,000 .

Table 1. Summary statistics for selected variables, CGSS (2006)

\begin{tabular}{|c|c|c|c|c|c|}
\hline Variables & Obs. & Mean & Std. Dev. & Min & $\operatorname{Max}$ \\
\hline $\mathrm{DV}=$ Demand for democracy & 9087 & .546 & .497 & 0 & 1 \\
\hline \multicolumn{6}{|l|}{$\mathrm{IV}=$ Group Indicator } \\
\hline Cadres & 10151 & .015 & .120 & 0 & 1 \\
\hline Entrepreneurs & 10151 & .021 & .145 & 0 & 1 \\
\hline Administrators SOEs & 10151 & .021 & .144 & 0 & 1 \\
\hline Intellectuals & 10151 & .032 & .176 & 0 & 1 \\
\hline Self-employed & 10151 & .112 & .315 & 0 & 1 \\
\hline White collars & 10151 & .012 & .107 & 0 & 1 \\
\hline Peasants & 10151 & .298 & .457 & 0 & 1 \\
\hline Workers & 10151 & .445 & .497 & 0 & 1 \\
\hline \multicolumn{6}{|l|}{ Covariates } \\
\hline Male & 10151 & .461 & .498 & 0 & 1 \\
\hline Age & 10151 & 42.390 & 13.448 & 18 & 70 \\
\hline Minority & 10151 & .066 & .247 & 0 & 1 \\
\hline \multicolumn{6}{|l|}{ Education } \\
\hline Primary & 10143 & .223 & .416 & 0 & 1 \\
\hline Middle school & 10143 & .332 & .471 & 0 & 1 \\
\hline High school & 10143 & .226 & .417 & 0 & 1 \\
\hline Some college + & 10143 & .120 & .325 & 0 & 1 \\
\hline Household income & 9201 & 21570.58 & 29795.71 & 150 & 600,000 \\
\hline
\end{tabular}

Note: $* \mathrm{P}<.05, * * \mathrm{P}<.01, * * * \mathrm{P}<.001$; standard errors are in the parenthesis. 
Table 2 displays the mean score of demand for democracy for the whole sample, for the subsample with CCP membership and the subsample without CCP membership, respectively. The difference in the mean score between CCP members and non-members is examined by t-test. Overall, the demand for democracy between people with CCP membership and without CCP membership differs significantly. A slightly more than half of the observations demands for democracy, while the mean score is 10 percent higher among CCP members $(63.83 \%)$ compared with non-CCP members $(53.69 \%)$ at $\mathrm{p}<.001$ level. The gap differs substantially across eight subgroups. For peasants with CCP membership, their score of demanding for democracy is notably higher than peasants without CCP membership at $\mathrm{p}=.001$ level. For workers, their overall scores are higher than peasants. Workers with CCP membership demonstrate a significant higher demand for democracy as well compared to Non-members. For the six remaining subgroups, the social elite group scores the highest, and the middle class stands somewhere in the middle. Specifically, 71.33 percent of cadres claimed their demand for democracy, 66.34 percent among entrepreneurs, 66.35 percent among administrators in SOEs, 69.9 percent among intellectuals, 55.95 percent among self-employed, and 56.52 among white collars. By and large, demand for democracy varies greatly among social groups.

Table 2. Demand for democracy by CCP membership vs. none CCP membership

\begin{tabular}{cclll}
\hline & Total & $\begin{array}{l}\text { CCP member } \\
(\mathrm{n}=835)\end{array}$ & $\begin{array}{l}\text { None CCP member } \\
(\mathrm{n}=8252)\end{array}$ & $\begin{array}{l}\text { t-test } \\
\text { (p-value })\end{array}$ \\
\hline $\begin{array}{c}\text { DV= Demand for Democracy-YES (\%) } \\
\text { The Entire Sample }\end{array}$ & 54.630 & 63.832 & 53.696 & 5.615 \\
& & $(.016)$ & $(.005)$ & $(.000)$ \\
\hline Breakdown by Eight Subgroups & & & & \\
Cadres & 71.330 & 77.333 & 64.705 & 1.672 \\
Private Entrepreneurs & & $(.048)$ & $(.058)$ & $(.096)$ \\
& 66.340 & 50.000 & 67.010 & 0.995 \\
Administrators in SOE & & $(.188)$ & $(.033)$ & $(.320)$ \\
& 66.350 & 71.052 & 60.824 & 1.568 \\
Intellectuals & & $(.042)$ & $(.049)$ & $(.118)$ \\
& 69.900 & 67.857 & 70.666 & .477 \\
Self-employed & & $(.051)$ & $(.030)$ & $. .633)$ \\
& 55.950 & 52.941 & 56.102 & .443 \\
White Collars & & $(.070)$ & $(.016)$ & $(.657)$ \\
& 56.520 & 40.000 & 58.095 & 1.099 \\
Peasants & & $(.163)$ & $(.048)$ & $(.274)$ \\
& 44.230 & 56.976 & 43.322 & 3.491 \\
Workers & & $(.037)$ & $(.010)$ & $(.001)$ \\
& 57.310 & 64.705 & 56.547 & 3.107 \\
& & $(.024)$ & $(.008)$ & $(.002)$ \\
\hline & & & &
\end{tabular}

Note: ${ }^{*} \mathrm{P}<.05,{ }^{*} \mathrm{P}<.01,{ }^{* * *} \mathrm{P}<.001 ;$ standard errors are in the parenthesis.

Table 3A presents estimated coefficients for binary logistic model of demand for democracy for various social groups. Model 1 reports the estimated coefficients for the public servant subgroup who work in either governmental institutions or state-owned enterprises (cadres and SOEs). Compared with other groups, the odds of demand for democracy are 45 percent higher among public servants $(\mathrm{p}=.004)$, other things being equal. The similar trend is identified for other subgroups. The estimated coefficients on the entrepreneurs, the elites group as a whole, and the CCP members are all significantly positive. Besides group identity, males, minorities and well-educated people raise the chances of demanding for democracy significantly. In terms of the estimated 
coefficients for the variable of household income, they are positive and statistically significant for public servant subgroup, the elite group as a whole and the CCP members all at the level of $p<.001$. The variable of age doesn't indicate its political effects in any subgroup.

Table 3B reports the results of logistic regression, and examines whether the interaction of CCP membership and group identity has effects on demand for democracy. Model 1-8 present the estimated coefficients for each of the eight subgroups. The effects of respondents' group identity in the Chinese societal hierarchy on demand for democracy are prominent. Model 1 shows that the odds of demanding for democracy among peasants are 37 percent lower than other groups $(\mathrm{p}<.001)$, other things being equal. As indicated by the statistically significant interaction term, holding CCP membership results in higher demand for democracy among peasants $(\mathrm{p}=.010)$. The same pattern is observed among workers with CCP membership. Model $1 \& 2$ verify our second hypothesis that the CCP members of the working class (peasants and workers) have higher demand for democracy compared with other groups. Model 5 \& 7 present the other two estimates with statistical significance. Both intellectuals and entrepreneurs are inclined to demand for democracy. But the interactions of group identity with the CCP membership fall short of statistical significance. Furthermore, the estimated coefficients for other covariates highlight that demand for democracy varies with different socioeconomic characteristics. For all the eight subgroups, being male, minority and better-educated are nice predictors of the likelihood of demanding for democracy. Household income works well only for peasant and white collars.

Table 3A. The Effects of vested interest groups on demand for democracy

\begin{tabular}{|c|c|c|c|c|}
\hline \multicolumn{5}{|c|}{ Dependent Variable $=$ Demand for Democracy } \\
\hline & Model 1: & Model 2: & Model 3: & Model 4 \\
\hline & Public Servants & Entrepreneur & Elite as a whole & Party Member \\
\hline \multicolumn{5}{|l|}{ Independent variables } \\
\hline Public Servants & $1.453(.188)^{* *}$ & & & \\
\hline Entrepreneur & & $1.391(.225)^{*}$ & & \\
\hline Elite as a whole & & & $1.153(.051)^{* * *}$ & \\
\hline Party member & & & & $1.334(.111)^{* * *}$ \\
\hline \multicolumn{5}{|l|}{$\begin{array}{l}\text { Socioeconomic } \\
\text { Characteristics }\end{array}$} \\
\hline Male & $1.123(.051)^{* *}$ & $1.121(.061)^{*}$ & $1.172(.057)^{* * *}$ & $1.105(.051)^{*}$ \\
\hline Age & $.998(.002)$ & $1.000(.002)$ & $.998(.001)$ & $.997(.002)$ \\
\hline Minority & $1.355(.128)^{* * *}$ & $1.523(.193)^{* * *}$ & $1.374(.138)^{* *}$ & $1.353(.128)^{* * *}$ \\
\hline \multicolumn{5}{|l|}{ Education } \\
\hline Primary & $1.148(.102)$ & $.927(.144)$ & $1.155(.114)$ & $1.142(.102)$ \\
\hline Middle & $1.472(.130)^{* * *}$ & $1.216(.181)$ & $1.499(.145)^{* * *}$ & $1.455(.129)^{* * *}$ \\
\hline High School & $1.607(.155)^{* * *}$ & $1.251(.191)$ & $1.628(.171)^{* * *}$ & $1.581(.153)^{* * *}$ \\
\hline College+ & $1.921(.224)^{* * *}$ & $1.767(.297)^{* * *}$ & $2.085(.267)^{* * *}$ & $1.894(.221)^{* * *}$ \\
\hline Log(income) & $1.123(.029)^{* * *}$ & $1.026(.036)$ & $1.113(.032)^{* * *}$ & $1.126(.029)^{* * *}$ \\
\hline \multicolumn{5}{|l|}{ Constant } \\
\hline Log likelihood & -5614.28 & -3771.80 & -4940.17 & -5612.54 \\
\hline $\mathrm{N}$ & 8267 & 8267 & 8267 & 8267 \\
\hline
\end{tabular}

$* \mathrm{P}<.05, * * \mathrm{p}<.01, * * * \mathrm{p}<.001$, odds ratio; standard errors are in the parenthesis. 
Table 3B. The effects of party membership on demand for democracy

\begin{tabular}{|c|c|c|c|c|c|c|c|c|}
\hline & $\begin{array}{l}\text { Model 1: } \\
\text { Peasant }\end{array}$ & $\begin{array}{l}\text { Model 2: } \\
\text { Worker }\end{array}$ & $\begin{array}{l}\text { Model 3: } \\
\text { W-Collar }\end{array}$ & $\begin{array}{l}\text { Model } 4 \\
\text { Getihu }\end{array}$ & $\begin{array}{l}\text { Model } 5 \\
\text { Intellectual }\end{array}$ & $\begin{array}{l}\text { Model } 6 \\
\text { SOEs }\end{array}$ & $\begin{array}{l}\text { Model } 7 \\
\text { Private_E }\end{array}$ & $\begin{array}{l}\text { Model } 8 \\
\text { Cadres }\end{array}$ \\
\hline \multicolumn{9}{|l|}{ Independent variables } \\
\hline \multirow[t]{2}{*}{ Group Identity } & .630 & .920 & .690 & .936 & 1.430 & .942 & 1.430 & 1.309 \\
\hline & $(.036)^{* * *}$ & $(.057)$ & $(.159)$ & $(.071)$ & $(.255)^{*}$ & $(.211)$ & $(.236)^{*}$ & $(.374)$ \\
\hline \multirow[t]{2}{*}{ Group * CCP } & 1.525 & 1.357 & .533 & .741 & .784 & 1.505 & .455 & 1.663 \\
\hline & $(.249)^{* *}$ & $(.159)^{* *}$ & $(.424)$ & $(.222)$ & $(.227)$ & $(.459)$ & $(.381)$ & (.693) \\
\hline \multicolumn{9}{|l|}{$\begin{array}{l}\text { Socioeconomic } \\
\text { Characteristics }\end{array}$} \\
\hline \multirow[t]{2}{*}{ Male } & 1.155 & 1.104 & 1.132 & 1.134 & 1.133 & 1.121 & 1.121 & 1.118 \\
\hline & $(.053)^{* *}$ & $(.061)$ & $(.051)^{* *}$ & $(.062)^{*}$ & $(.051)^{* *}$ & $(.061)^{*}$ & $(.061)^{*}$ & $(.061)^{*}$ \\
\hline \multirow[t]{2}{*}{ Age } & .997 & .999 & .999 & .999 & .999 & .999 & 1.000 & .999 \\
\hline & $(.002)$ & $(.002)$ & $(.001)$ & $(.002)$ & $(.001)$ & $(.002)$ & $(.002)$ & $(.002)$ \\
\hline \multirow[t]{2}{*}{ Minority } & 1.409 & 1.527 & 1.357 & 1.525 & 1.362 & 1.519 & 1.526 & 1.530 \\
\hline & $(.134)^{* * *}$ & $(.194)^{* * *}$ & $(.129)^{* * *}$ & $(.193)^{* * *}$ & $(.129)^{* * *}$ & $(.193)^{* * *}$ & $(.194)^{* * *}$ & $(.194)^{* * *}$ \\
\hline \multicolumn{9}{|l|}{ Education } \\
\hline \multirow[t]{2}{*}{ Primary } & 1.124 & .932 & 1.152 & .923 & 1.153 & .926 & .928 & .924 \\
\hline & $(.101)$ & $(.144)$ & $(.102)$ & $(.143)$ & $(.102)$ & $(.143)$ & $(.144)$ & $(.143)$ \\
\hline \multirow[t]{2}{*}{ Middle } & 1.334 & 1.215 & 1.485 & 1.208 & 1.487 & 1.208 & 1.216 & 1.206 \\
\hline & $(.120)^{* *}$ & $(.181)$ & $(.131)^{* * *}$ & $(.181)$ & $(.131)^{* * *}$ & $(.180)$ & $(.181)$ & $(.180)$ \\
\hline \multirow[b]{2}{*}{ School } & 1.366 & 1.241 & 1.635 & 1.234 & 1.640 & 1.238 & 1.252 & 1.229 \\
\hline & $(.135)^{* *}$ & $(.191)$ & $(.157)^{* * *}$ & $(.190)$ & $(.158)$ & $(.190)$ & $(.191)$ & $(.188)$ \\
\hline \multirow[t]{2}{*}{ College +} & 1.670 & 1.684 & 2.119 & 1.714 & 1.889 & 1.703 & 1.769 & 1.678 \\
\hline & $(.196)^{* * *}$ & $(.284)^{* *}$ & $(.246)^{* * *}$ & $(.291)^{* *}$ & $(.230)$ & $(.288)^{* *}$ & $(.297)^{* * *}$ & $(.282)^{* *}$ \\
\hline \multirow[t]{2}{*}{ Log (income ) } & 1.060 & 1.034 & 1.132 & 1.033 & 1.129 & 1.033 & 1.026 & 1.033 \\
\hline & $(.029)^{*}$ & $(.036)$ & $(.029)^{* * *}$ & $(.036)$ & $(.029)$ & $(.036)$ & $(.036)$ & $(.036)$ \\
\hline Log likelihood & -5586.45 & -3770.12 & -5616.53 & -3772.83 & -5616.50 & -3772.56 & -3771.37 & -3769.91 \\
\hline $\mathrm{N}$ & 8267 & 8267 & 8267 & 8267 & 8267 & 8267 & 8267 & 8267 \\
\hline
\end{tabular}

$* \mathrm{P}<.05, * * \mathrm{p}<.01, * * * \mathrm{p}<.001$, odds ratio, standard errors are in the parenthesis.

The four models in Table 4 display the coefficient estimations from logistic regression of three democratic activities: mass gathering, protesting and striking. Estimates in Model 1 show that the social elite group strongly opposes democratic participations, and the odds of supporting mass gathering, protesting and striking in this group is decreased by 22.8 percent $(\mathrm{p}=.012), 24.6$ percent $(\mathrm{p}=.016)$, and 22.6 percent $(\mathrm{p}=.034)$, respectively. Model 2 presents the similar trends among CCP members. The CCP members demonstrate a significantly less support for political rights. Model 3 presents the estimates among peasant CCP members. Similar with Model 2, peasant CCP members are less likely to support for mass gathering $(p=.009)$ and protesting $(p=.003)$. Though our regression analysis does not identify attitudes of the CCP member among workers, I find strong evidence that verifies the third hypothesis that the social elite group and CCP members are resistant to democratic activities such as mass gathering, protesting and striking.

Model 1 in Table 5 reports the Ordinary Least Squares (OLS) regression estimates for models of perceived socioeconomic well-beings, with the social elite group as the key independent variable, and age, gender, minority, education and household income as controlled covariates. For simplicity, I don't report the regression estimates for covariates. Model 2-4 report the estimates for the CCP membership, the CCP members of peasants and the CCP workers, respectively. In Model 1, a social elite brings about 7.3 percentage point increase in 
current happiness with statistical significance ( $\mathrm{p}=.029)$, holding constant of the other factors. As expected, being the social elite group is also associated with a perceived increase in income in past three years, but falls short of statistical significance ( $\mathrm{p}=.696)$. In Model 2, being a CCP member is associated with an increase in income by 6.6 percentage point $(p=.014)$, and 14 percentage point increase in current happiness $(p<.001)$. Model 3 and Model 4 examine whether the similar pattern exists within the working class CCP members. It turns out that the effects of CCP membership on subjective well-being are stronger among peasants and workers. In Model 3, being a peasant CCP member is associated with an increase in income by 26 percentage points $(\mathrm{p}<.001)$ and happiness by 25 percentage points $(\mathrm{p}<.001)$. In Model 4, holding CCP membership as a worker is associated with an increase in income by 8.9 percentage points $(\mathrm{p}=.017)$, and an increase in happiness by 14.3 percentage points $(\mathrm{p}<.001)$.

Table 4. The effects of group identity on three democratic activities

\begin{tabular}{lllll}
\hline & $\begin{array}{l}\text { Model 1: } \\
\text { Elite as a whole }\end{array}$ & $\begin{array}{l}\text { Model 2: } \\
\text { CCP membership }\end{array}$ & $\begin{array}{l}\text { Model 3: } \\
\text { CCP peasant }\end{array}$ & $\begin{array}{l}\text { Model 4 } \\
\text { CCP worker }\end{array}$ \\
\hline DV1= Mass Gathering & .772 & .760 & .643 & .957 \\
& $(.079)^{* *}$ & $(.064)^{* * *}$ & $(.109)^{* *}$ & $(.108)$ \\
DV2= Protest & .754 & & & \\
& $(.088)^{* *}$ & $(.067)^{* * *}$ & $(.112)^{* *}$ & .892 \\
& & & & $(.112)$ \\
DV3= Strike & .774 & .740 & .735 & .894 \\
& $(.093)^{*}$ & $(.073)^{* * *}$ & $(.143)$ & $(.117)$ \\
\hline Covariates & - & & - & - \\
$\mathrm{N}$ & 8321 & 8321 & 8321 & 8321 \\
\hline
\end{tabular}

${ }^{*} \mathrm{P}<.05,{ }^{* *} \mathrm{p}<.01,{ }^{* * *} \mathrm{p}<.001$, odds ratio, standard errors are in the parenthesis.

Table 5. The effects of group identity on current well-being

\begin{tabular}{lllll}
\hline & $\begin{array}{l}\text { Model 1: } \\
\text { Elite as a whole }\end{array}$ & $\begin{array}{l}\text { Model 2: } \\
\text { CCP membership }\end{array}$ & $\begin{array}{l}\text { Model 3: } \\
\text { CCP peasant }\end{array}$ & $\begin{array}{l}\text { Model 4 } \\
\text { CCP worker }\end{array}$ \\
\hline DV1=An Increase in & .012 & .066 & .260 & .089 \\
Income in past 3 years & $(.033)$ & $(.027)^{*}$ & $(.051)^{* * *}$ & $(.037)^{*}$ \\
& & & & \\
DV2= Current Happiness & .073 & .140 & .251 & .143 \\
& $(.033)^{*}$ & $(.027)^{* * *}$ & $(.054)^{* * *}$ & $(.038)^{* * *}$ \\
\hline Covariates & - & & - & - \\
$\mathrm{N}$ & 8279 & 8279 & 8279 & 8279 \\
\hline
\end{tabular}

$* \mathrm{P}<.05, * * \mathrm{p}<.01,{ }^{* * *} \mathrm{p}<.001$, odds ratio, standard errors are in the parenthesis.

\section{Discussion and Conclusion}

The empirical outcome that the CCP members especially the CCP members of the working class have a stronger preference over the democratic principles implies these leading class people in the Mao era have been politically marginalized and are discontented with the political changes since the reform. The number of party members increased from 38 million in 1980 to 70.8 million in 2005 . By the end of $2005,29 \%$ of party members are workers and peasants while the government officials only account for $8.1 \%$. Although the party namely defines the Chinese elites, only about 70 out of 1 million members hold positions in the party bureaucracy (Lieberthal, 2004). Since the 1980s, more and more well-educated young party members have been promoted into the party 
bureaucracy. The previous working class political elites in 1970s such as Chen Yonggui and Wu Guixian have been moved out of the political arena. At the $16^{\text {th }}$ Party Congress in 2002, the private entrepreneurs were officially allowed to join the party. As a result, a growing number of grassroots members are disappointed with these political changes during the reform and looking for democracy to express their discontent to the political system.

Cadres and SOEs administrators' support to democracy may be a response to the pervasive bureaucratic corruption from the insiders' view. In the process of China's decentralized economic reform, the top local official or yibashou (Number-One Leader) have become the independent political monopolist (Pei, 2006). According to a survey made by the CCP Organization Department in Sichuan Province in 1999, about one third party members thought the local leaders enjoyed the monopoly power in decision making process (Organization Department, 1999). From 1993 to 2003 in Henan province, 4,123 yibashou corruption cases were investigated, about $40 \%$ of yibashou were chief executives of SOEs (Xin Hua News, 2004). On the other hand, it is extremely important for those ordinary cadres or SOEs administrators to keep a good individual relationship (guanxi) with leaders in power to get career mobility (Lieberthal, 2004). Thus they have a close eye and personal experience on various disadvantages of the cadres' administration system.

Based on the above analyses, the apparent demand for democracy from the CCP members and cadres corresponds to some policies implemented since the 1980s. Their attitudes towards democratic principles can hardly be viewed as a discontent with the CCP regime as a whole. The signal of democratic impulses does not necessarily mean a political transition is supported in the Chinese context. On the contrary, those who show a stronger demand for democracy significantly oppose various democratic activities as well. The multiple regression models have identified the $\mathrm{CCP}$ working class and cadres are pretty satisfied with their well-being in the reform era. China's economic reform before the early 1990s is characterized as a Pareto-improving reform or a "reform without losers" (Lau, Qian, \& Roland, 2000). Although the large-scaled privatization reform has produced losers (Qian, 2003) since the 1990s and was associated with social unrests, many of these collective incidents are loyalist protest or economic-oriented (Lorentzen, 2013). In rural China, A popular social movement is named "Rightful Resistance" (O'Brien \& Li, 2006). In sum, most of citizens' discontents or protests in the reform China do not challenge the legitimacy of CCP. Rather, they are looking for a peaceful channel which is conditional on social order to influence the direction of the reform. Certainly, there are many alternative explanations on why those who demand for democracy do not support democratization in China. The dependence theory of the middle class, for instance, contends that the Chinese entrepreneurs and middle class's economic status is not independent from the CCP government. Some scholars don't think the private entrepreneurial class has been formed in China (Tsai, 2005 and 2007). If the legitimacy of CCP is the pre-condition to keep China's economy moving forward, the dependence theory of the middle class can be applied to explain why CCP members and cadres oppose democratic movements as well.

This paper contributes to the conventional modernization theory of political development in two ways. First, in some developing countries like China, a strong demand for democracy may come from the most discontent groups rather than the well-educated middle class. Second, those who want democracy in developing countries do not necessarily support democratization as their political demand may just be a signal of disagreement with government policies rather than the legitimacy of the government. In the Chinese context, party members as well as cadres oppose democratic activities significantly. The entrepreneurs and the middle class do not perform as what they are expected according to the modernization theory. The demand for democracy in China is more likely to be an expression of discontent with the current political system rather than the democratic impulses and the Chinese democratization may not be as optimistic as many optimists predicted.

\section{References}

Brodsgaard, E. (2002). Institutional reform and the Bianzhi system in China. The China Quarterly, 170, 361-386. http://dx.doi.org/10.1017/S0009443902000232

Cai, Y. (2004). Managed participation in China. Political Science Quarterly, 119(3), 425-451. http://dx.doi.org/10.2307/20202390

Chen, A. (2002). Capitalist development, entrepreneurial class, and democratization in China. Political Science Quarterly, 117(3), 401-422. http://dx.doi.org/10.2307/798262

Chen, J., \& Lu, C. (2011). Democratization and the middle class in China: The middle class's attitudes toward democracy. Political Research Quarterly, 64(3), 705-719. http://dx.doi.org/10.1177/1065912909359162 
Chen, J., \& Zhong, Y. (2000). Valuation of individual liberty vs. social order among democratic supporters: A $\begin{array}{llll}\text { cross validation. Political Research } & \text { Quarterly, }\end{array}$ http://dx.doi.org/10.1177/106591290005300210

Chen, Y., Li, H., \& Zhou, L. (2005). Relative performance evaluation and the turnover of provincial leaders in China. Economics Letters, 88(3), 421-425.

Demick, B. (2012). Protests in China over local grievances surge, and get a hearing. Retrieved from http://articles.latimes.com/2011/oct/08/world/la-fg-china-protests-20111009

Fewsmith, J. (2007). The political implications of China's growing middle class. China Leadership Monitor, 21, $1-8$.

Goldman, M., \& MacFarquhar, R. (1999). The paradox of China's post-Mao reforms. Cambridge, Massachusetts: Harvard University Press.

Heberer, T., \& Schubert, G. (2006). Political reform and regime legitimacy in contemporary China. ASIEN, 99, $9-28$.

Holbig, H., \& Gilley, B. (2010). Reclaiming legitimacy in China. Politics \& Policy, 38(3), 395-422. http://dx.doi.org/10.1111/j.1747-1346.2010.00241.x

Lau, L., Qian, Y., \& Roland, G. (2000). Reform without losers: An interpretation of China's dual-track approach to transition. Journal of Political Economy, 108(1), 120-143.

Li, C. (2007). China in the year 2020: Three political scenarios. Asia Policy, 4, 17-29.

Li, L. (2004). Political trust in rural China. Modern China, 30(2), 228-258.

Li, H., Meng, L., \& Zhang, J. (2006). Why do entrepreneurs enter politics? Evidence from China. Economic Inquiry, 44(3), 559-578. http://dx.doi.org/10.1093/ei/cbj031

Li, H., \& Zhou, L. (2005). Political turnover and economic performance: The incentive role of personnel control in China. Journal of Public Economics, 89, 1743-1762. http://dx.doi.org/10.1016/j.jpubeco.2004.06.009

Lieberthal, K. (2004). Governing China: From revolution to reform. New York, NY: Norton, W. W., \& Company, Inc.

Liou, K. (2000). State-society relations in post-Mao Chinese economic reforms: Changes and challenges. International Journal of Economic Development, 2(1), 132-154.

Lipset, S. (1959). Some social requisites of democracy: Economic development and political legitimacy. The American Political Science Review, 53(1), 69-105. http://dx.doi.org/10.2307/1951731

Liu, Y., \& Chen, D. (2012). Why China will democratize? The Washington Quarterly, 35(1), 41-63.

Lorentzen, P. (2013). Regularizing rioting: Permitting public protest in an authoritarian regime. Quarterly Journal of Political Science, 8(2), 127-158. http://dx.doi.org/10.1561/100.00012051

Mesquita, B., \& Downs, G. (2005). Development and democracy. Foreign Affairs, 84(5), 77-86.

Moore, B. (1966). Social origins of dictatorship and democracy: Lord and peasant in the making of the modern world. Boston, Massachusetts: Beacon Press.

Nande Group. (1997). Private Economy in China. Retrieved from http://www.nandegroup.com/xgbd/x042.html

Naughton, B. (2003). State enterprise restructuring: Renegotiating the social compact in urban China. In T. Fisac, \& L. Fernandez-Stembridge (Eds.), China today: Economic reforms, social cohesion and collective identities. New York, NY: Routledge.

O’Brien, K. (1996). Rightful resistance. World Politics, 49(1), 31-55. http://dx.doi.org/10.1353/wp.1996.0022

O'Brien, K., \& Li, L. (2006). Rightful resistance in rural China. Cambridge, Massachusetts: Cambridge University Press.

Organization Department of Chinese Communist Party. (1999). Sichuansheng dangzheng lingdao banzi chengyuan sixiang zhengzhi sushi zhuangkuang diaocha baogao ("An investigation report on the status of ideological and political caliber of prefectural and county party and government officials in Sichuan Province") In Zuzhi gongzuo yanjiu wenxuan (Selected Essays on Organizational Work). Beijing, China: Party Readings Press. 
Pearson, M. (1997). China's new business elite: The political consequences of economic reform. Oakland, California: University of California Press.

Pei, M. (2006). China's trapped transition: The limits of developmental autocracy. Cambridge, Massachusetts: Harvard University Press.

Pei, M. (2007). How will China democratize? Journal of Democracy, 18(3), 53-57.

Perry, E., \& Selden, M. (2003). Chinese society: Change, conflict and resistance. New York, NY: Routledge Press.

Qian, Y. (2003). How reform worked in China. In D. Rodrik (Ed.), Search of prosperity: Analytic narratives on economic growth. Princeton, NJ: Princeton University Press.

Rowen, H. (2007). When will the Chinese people be free? Journal of Democracy, 18(3), 38-52.

Tang, M. (2011). The political behavior of the Chinese middle class. Journal of Chinese Political Science, 16, 373-387. http://dx.doi.org/10.1007/s11366-011-9166-y

Thompson, M. (2001). To shoot or not to shoot: Post-totalitarianism in China and Eastern Europe. Comparative Politics, 34(1), 63-83.

Tsai, K. (2005). Capitalists without a class: Political diversity among private entrepreneurs in China. Comparative Political Studies, 38(9), 1130-1158. http://dx.doi.org/10.1177/0010414005277021

Tsai, K. (2007). Capitalism without democracy: The private sector in contemporary China. Ithaca, NY: Cornell University Press.

Xin Hua News, (2004). Anti-corruption in China. Retrieved from http://news.xinhuanet.com/legal/2004-02/17/content_1318838.htm

Yang, D. (2004). Remaking the Chinese Leviathan: Market transition and the politics of governance in China. Stanford, California: Stanford University Press.

Yu, J. (2007). Riots and governance crisis in China. Retrieved from http://www.aisixiang.com/data/16434.html

Zheng, Y. (1994). Development and democracy: Are they compatible in China? Political Science Quarterly, $109(2), 235-259$.

Zheng, Y. (2004). Will China become democratic? Singapore: Eastern Universities Press.

\section{Copyrights}

Copyright for this article is retained by the author(s), with first publication rights granted to the journal.

This is an open-access article distributed under the terms and conditions of the Creative Commons Attribution license (http://creativecommons.org/licenses/by/3.0/). 